\title{
Assessing the histological changes in fish gills as environmental bioindicators in Paraty and Sepetiba bays in Rio de Janeiro, Brazil
}

\author{
Thatiana Luiza Assis de Brito Carvalho ${ }^{1}$, Aparecida Alves do Nascimento ${ }^{2}$ \\ Caio Fábio dos Santos Gonçalves ${ }^{3}$ Marcos Antônio José dos Santos ${ }^{2}$ \& Armando Sales ${ }^{2}$ \\ ${ }^{1}$ Programa de Pós-Graduação em Biologia Animal, Universidade Federal \\ Rural do Rio de Janeiro Seropédica, RJ, Brazil \\ ${ }^{2}$ Instituto de Ciências Biológicas e da Saúde, Departamento de Biologia Animal, Área de Histologia \\ e Embriologia, Universidade Federal Rural do Rio de Janeiro, Seropédica, RJ, Brazil \\ ${ }^{3}$ Discente do curso de Medicina Veterinária Universidade Federal Rural do Rio de Janeiro \\ Seropédica, Brazil, RJ, Brazil \\ Corresponding author: Thatiana L. Assis (thati.lu@yahoo.com.br)
}

\begin{abstract}
The use of fish species uses as bioindicators is an important environmental monitoring tool. Histological biomarkers are adopted to assess the health conditions of different organisms and to indicate an environmental hazard. Histology can be applied as an effective method to analyze the effects of pollutants and other stressors. Accordingly, histological changes in the gill epithelium were analyzed to assess the adoption of fish species Menticirrhus americanus (Linnaeus, 1758) and Micropogonias furnieri (Desmarest, 1823) as a bioindicator to measure environmental quality in Paraty and Sepetiba bays, in Rio de Janeiro. A random sample of 58 fish was collected from the assessed bays. We found Paraty Bay to be in good conservation condition, whereas Sepetiba Bay is contaminated. The fish species collected from Sepetiba Bay showed lesions such as epithelial lifting, aneurysm, and necrosis in the gills; thus, it was possible to suggest that histological biomarkers be used bioindicators to measure the environmental impact in these bays.
\end{abstract}

Keywords: Sciaenidae; morphology; mucous cells; histological biomarkers; estuary; Rio de Janeiro

\section{INTRODUCTION}

The discharge of waste from agriculture, industries, and urban activities into aquatic ecosystems results in the production of a wide variety of organic and inorganic pollutants. Aquatic environments around industrial units are at high risk of contamination by pollutants such as petrochemicals, solvents, oils, and heavy metals (Rajamanickam \& Narayanan, 2009). Increased pollution in aquatic ecosystems leads to severe morphological and physiological changes in aquatic organisms (Mazon et al., 1999; Zhou et al., 2008). Chemical and physical parameters are used as biomarkers to monitor aquatic pollution and to evaluate the adverse effects of heavy metals on aquatic organisms (Van der Oost et al., 2003; Au, 2004).

Over the past few years, there has been an increase in the concentration of heavy metals and nutrients in natural waters that receive municipal and industrial waste. Heavy metals represent all environmental pollutants' major hazards due to their toxicity and bioaccumulative nature (Elnaggar et al., 2009). The relationship between metal accumulation and the feeding behavior of a species reflects the crucial role of bioavailability of different metals in the aquatic environment and the trophic transfer to the food web (Monperrus et al., 2005). Fish is the primary aquatic organism that accumulates considerable amounts of heavy metals exceeding their concentrations in the aquatic ecosystem (Ambedkar \& Muniyan, 2011). Thus, determining the degree of pollution is of great importance for assessing the potential impact of heavy metals on the environment (Samanidou et al., 1991).

Fish are at the apex of the aquatic food chain, so they are good bioindicators of contamination caused by heavy metals (Hemmadi, 2017). Animals from contami- 
nated sites are proven to be great bioindicators (Livingstone, 2003). Moreover, histological changes have been widely used as biomarkers to evaluate the health condition of fish exposed to contaminants and to explain the mechanism of action adopted by several stress agents (Hinton et al., 1992; Schwaiger et al., 1997; Teh et al., 1997; Camargo \& Martinez, 2007; Bertoletti, 2008; Nascimento et al., 2012). These changes are a quick method to detect the effects of irritants, mainly chronic ones, on different tissues and organs (Johnson et al., 1993; Velmurugan et al., 2009). Identifying early warning signals through branchial lesions is ecologically and economically relevant, as well as faster; besides, they have the potential to be used as biomarkers (Sousa et al., 2013).

Gills of fish are efficient biomonitoring tools due to their large surface area, which has direct and permanent contact with potential irritants (Bernet et al., 1999; Sweidan et al., 2015). Gills are responsible for respiratory gas exchange and play an essential role in osmoregulation and acid-base regulation (Fernandes \& Mazon, 2003; Fernandes et al., 2007). They are the first organs that respond to unfavorable environmental changes (Benli et al., 2008). Changes in the epithelium of gills can be due to exposure to a variety of contaminants, and the severity of such alterations depends on the concentration of these pollutants and the exposure time (Franchini et al., 1994; Evans et al., 2005; Gomes et al., 2012). Moreover, they are early warning signs about fish health conditions (Sorour, 2001). Studies have shown that the degree of morphological lesions in the gills can delimit the degree of environmental pollution (Thophon et al., 2003; Camargo \& Martinez, 2007; Akinloye et al., 2009; Flores-Lopes \& Thomaz, 2011). Disorders affecting ion regulation and gas exchange, which are processes partly performed by gills (Verbost et al., 1995; Evans, 1997; Ledy et al., 2003), are among the main impacts of pollution. Furthermore, mucous cells in gills play an essential role in the resistance of fish to toxic substances (Bernet et al., 1999), to abrasive injuries caused by solid materials suspended in water (Dezfuli et al., 2003) and to pollutants (Ledy et al., 2003; Roberts \& Powell, 2003).

Menticirrhus americanus (Linnaeus, 1758) and Micropogonias furnieri (Desmarest, 1823) belong to the family Sciaenidae; these fish species are distributed in the continental shelf region and in estuarine areas that hold a significant diversity of life forms and habitats (Menezes \& Figueireido, 1980). Sciaenidae accounts for the highest number of species in southeastern Brazil and is one of the most important demersal fishery resources (Vazzoler et al., 1999). These species can be found in several environments, a fact that suggests their high ecophysiological plasticity, as well as their tolerance to a wide range of variations in water physical and chemical parameters; therefore, they are suitable for environmental monitoring purposes. The objectives of this study were 1) to evaluate histological changes in fish gills caused by pollution and to analyze their use as biomarkers to measure environmental impacts, 2) to compare the response of mucous cells of fishes living in Paraty and Sepetiba bays, as well as 3) to determine whether $M$. americanus and M. furnieri are suitable to be used as biomonitoring tools.

\section{MATERIALS AND METHODS}

\section{Study site}

Sepetiba Bay $\left(22^{\circ} 54^{\prime}-23^{\circ} 04^{\prime} \mathrm{S}, 4^{\circ} 34^{\prime}-44^{\circ} 10^{\prime} \mathrm{W}\right)$ is located in Rio de Janeiro State, southeastern Brazil. Its area covers $520 \mathrm{~km}^{2}$ and houses a wide variety of habitats such as mangroves, sandbanks, and small estuaries (Fig. 1). The drainage basin in this bay serves a population of approximately two million people and over 400 industries, including metallurgy, petrochemical, and pyrometallurgy smelters (Molisani et al., 2004; IBGE, 2016). The bay is $5 \mathrm{~m}$ deep, on average, and its water is rich in organic nutrients derived from continental drainage; its bottom is predominantly muddy (Barbiéri \& Kronemberger, 1994). Sepetiba Bay plays an important role in the regional aquatic ecology; it is mainly important for juvenile fish that use the area as a nursery ground. Industries in the Sepetiba region develop activities responsible for the generation of waste rich in $\mathrm{Cd}$ and $\mathrm{Zn}$ (Lacerda et al., 1982; Molisani et al., 2004). Moreover, this bay has been severely affected by anthropogenic activities over the past 40 years (Pizzochero et al., 2019) because materials and contaminants discarded in it have changed its ecosystem (Wasserman et al., 2001).

Paraty Bay $\left(23^{\circ} 13^{\prime} 04^{\prime \prime} \mathrm{S}, 44^{\circ} 42^{\prime} 47^{\prime \prime} \mathrm{W}\right)$ is a small bay inside Ilha Grande Bay, southeastern Rio de Janeiro (Fig. 1). It was used as a reference environmental protection area; the 1988 Federal Constitution has protected it as a Union asset. The legislation aims at safeguarding its biota. Nowadays, it was granted with the status of World Heritage Site by the UNESCO (Organização das Nações Unidas para a Educação, a Ciência e a Cultura). Its area covers 65,258 ha, and its perimeter accounts for approximately $350 \mathrm{~km}^{2}$ (Creed et al., 2007). Paraty Bay is located between the two largest Brazilian cities, Rio de Janeiro and São Paulo. It is strongly influenced by oceanic water and houses several smaller embayments such as Ribeira and Jacuacanga (Figueiredo et al., 2008). Although Paraty Bay faces the deposition of atmospheric contaminants 


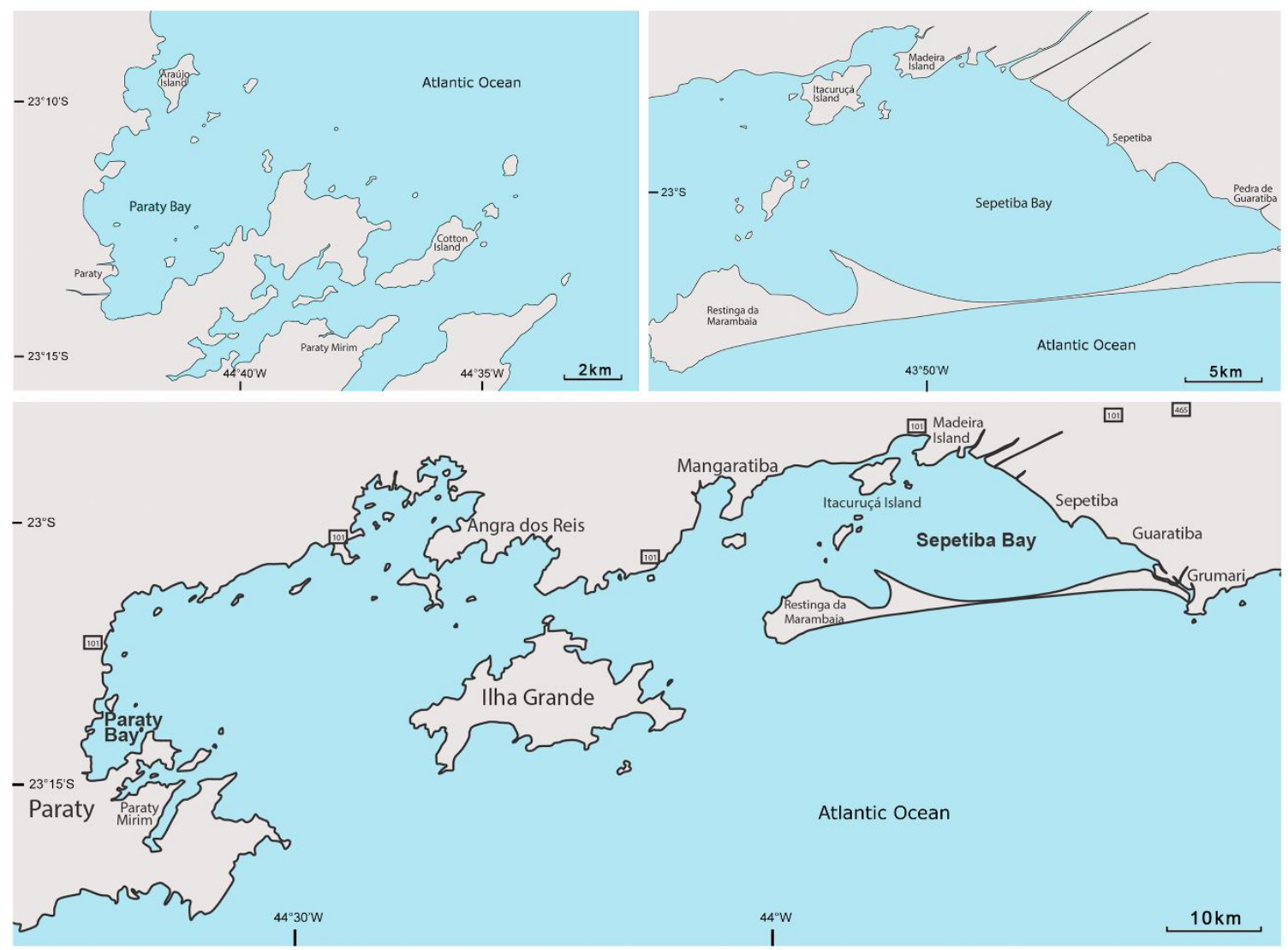

Figure 1. Brazilian coast map showing the study sites.

from São Paulo and Rio de Janeiro, it is categorized as a non-polluted area and has a relatively pristine natural ecosystem (Molisani et al., 2004; Wanick et al., 2011). The aquatic environment in the region does not seem to suffer from the environmental hazard, despite the high incidence of contamination sources. According to some research scholars, Paraty Bay is a reference area given its low level of heavy metals such as $\mathrm{Ni}, \mathrm{Cu}, \mathrm{Cr}, \mathrm{Mn}$, $\mathrm{Zn}$ and $\mathrm{Hg}$, a fact that justifies its categorization as an area non-contaminated by anthropogenic sources (Lacerda et al., 1982; Cardoso et al., 2001; FreretMeurer et al., 2010; Wanick et al., 2011).

\section{Water data}

Water analysis was carried out at the collection site based on the following physical and chemical parameters: temperature, $\mathrm{pH}$, dissolved oxygen (DO), and turbidity. A probe (Horiba ${ }^{\circledR} \bmod$. U-22/Water Quality-Checker) calibrated before each collection procedure was used for the analysis. Readings were conducted $1.0 \mathrm{~m}$ deep in water. The water samples were obtained in Paraty Bay (8 collects) and Sepetiba Bay (12 collects).

\section{Fish sampling}

Thirty adult fish specimens from Paraty Bay (12 Menticirrhus americanus and 18 Micropogonias furnieri) and 28 from Sepetiba Bay (12 M. americanus and $16 \mathrm{M}$. furnieri) were collected during the rainy, and a specialist supervised dry seasons in 2015 and 2016 by professionals using gill nets, and the procedure. After collection, fish species were identified, anesthetized with benzocaine hydrochloride $\left(50 \mathrm{mg} \mathrm{L}^{-1}\right)$, as recommended by Resolution 1000 from the Federal Council of Veterinary Medicine in 2012 for fish euthanasia, euthanized through hypothermia, measured and weighed. All fish were immersed in formaldehyde solution after euthanasia to diffuse post-mortem changes. The ICMBio license approved the current research for fish collection under process number 10707. Collected specimens were taken to the laboratory of histological techniques of Rio de Janeiro Federal Rural University (UFRRJ) and the Fish Ecology Laboratory of the Animal Biology Department, UFRRJ.

The mean size (length) of $M$. americanus ranged between 17.2 and $23.4 \mathrm{~cm}$, and its body weight ranged from 48.5 to $99.3 \mathrm{~g}$, whereas the mean length of $M$. 
furnieri ranged from 20.1 to $30.2 \mathrm{~cm}$ and its body weight ranged from 128.5 to $251.5 \mathrm{~g}$. M. furnieri presented wide variations in body size than $M$. americanus, a comparatively small-sized species, but all individuals were adults; sex was not considered.

Fish were dissected, the first gill arch from one of the sides of each fish was excised, but filaments were kept intact. The removed gill was fixed in $10 \%$ buffered formalin for $24 \mathrm{~h}$.

\section{Histological changes and mucous cell analysis}

Gills were dehydrated in increasing alcohol concentrations, cleared with xylene, and soaked in paraffin under laboratory conditions. Sagittal sections ( $4 \mu \mathrm{m}$ thick) were cut, mounted on glass slides, and stained with hematoxylin and eosin for histological description. Mucins were visualized in Alcian Blue (AB) at $\mathrm{pH} 2.5$ (acid glycoconjugates) and in periodic acid-Schiff (Santos et al., 2011) (neutral glycoconjugates). Sections of each fish gill were examined and photographed using Olympus $\mathrm{B} \times 41$ microscopeequipped with Nikon Coolpix 4300 digital camera.

Histological changes in gill tissues were classified based on scores from 0 to 3 , wherein $0=$ no changes, 1 $=$ slight changes, $2=$ moderate changes, and $3=$ severe changes (Flores-Lopes \& Thomaz, 2011). Minor changes do not damage gill tissues, so the restructuring and recovery of normal gill functions occur as environmental conditions improve. Among these changes, one finds interstitial edema, leukocyte infiltration, lamellar epithelium hyperplasia, lamellar fusion, vasodilatation, and lamellar blood congestion. Moderate changes are more severe and affect tissues associated with gill functioning; however, they are reparable, except when vast gill areas are affected or kept under chronic pollution conditions. Among these changes, one finds the epithelial lifting. Regardless of improvements in water quality or lack of exposure to toxic stimuli, severe changes do not allow gill structure to recover; among these changes, one finds lamellar aneurysms and necrosis (Nascimento et al., 2012). The histopathologic alterations index (HAI) (Poleksic \& MitrovicTutundzic, 1994) is based on lesion severity; it classifies changes of each organ based on progressive tissue damage stages for the determination of HAI (Poleksic \& Mitrovic-Tutundzic, 1994; Nascimento et $a l ., 2012)$. The HAI values of each animal were calculated according to the following formula: HAI = $(1 \times \mathrm{SI})+(10 \times \mathrm{SII})+(100 \times \mathrm{SIII})$, wherein I, II and III correspond to the number of changing stages 1,2 and 3 ; and $\mathrm{S}$ represents the sum of the number of changes at each particular stage. HAI values ranging from 0 to 10 indicate normal organ functioning, values between 11 and 20 indicate slight changes in the organ, values ranging between 21 and 50 indicate moderate changes in the organ, values ranging from 51 to 100 indicate severe lesions and values greater than 100 indicate irreparable organ lesions (Poleksic \& MitrovicTutundzic, 1994).

The percentage of each anomaly observed in the gill tissue of the two fish species collected in each bay was calculated by dividing the number of fish presenting a given anomaly by the total number of examined fish (Table 2). The number of gill mucous cells (Ledy et al., 2003) per individual was determined in the light microscope (at 40x) by examining three filament regions (base, middle, and apex), four filaments per section and three sections separated by at least four interval sections. Every examined region comprised ten adjoining lamellae and their associated interlamellar spaces on each side of the filament. In total, 36 measurements were taken per individual. Sections were examined using the Hund H600 Wetzlar microscope (40x).

\section{Statistical analysis}

The differences between sites and species were tested based on each parameter. Significant differences were compared using the binomial $t$-test for independent samples or using the Mann-Whitney $U$-test. Bonferroni correction was used to adjust $P$ values to minimize type I errors.

\section{RESULTS}

\section{Water analysis}

According to CONAMA resolution $\mathrm{N}^{\circ} 357$ that sets limits for parameters or indicators related to data about the protection of aquatic communities (class 1) DO concentrations should not record less than $5 \mathrm{mg} \mathrm{L}^{-1}$ to 40 NTU turbidity and pH should be kept between 6.5 and 8.5.

Paraty and Sepetiba bays presented DO concentrations and $\mathrm{pH}$ values within limits determined by the resolution mentioned above in all collections. Turbidity values were higher in Sepetiba Bay, although it did not exceed the limit set by CONAMA (40 NTU). On the other hand, Paraty Bay presented turbidity values below the limits established to it. Results of water physical and chemical analysis carried out at the sampling sites are shown in Table 1.

\section{Histological changes in gills}

We observed no significant differences between species in all histological changes. As expected, the analysis of all gills obtained from fish collected at Sepetiba Bay showed HAI equal to 100, indicating irre- 
Table 1. Physical and chemical analysis of the water from the collection sites. SD: Standard deviation.

\begin{tabular}{lrrr}
\hline \multirow{2}{*}{ Parameter } & \multicolumn{1}{c}{ Sepetiba Bay } & & Paraty Bay \\
\cline { 2 - 2 } & \multicolumn{1}{c}{ Mean \pm SD } & & Mean \pm SD \\
\hline Temperature $\left({ }^{\circ} \mathrm{C}\right)$ & $27.24 \pm 0.22$ & & $28.03 \pm 0.09$ \\
Dissolved oxygen & $6.40 \pm 0.26$ & & $5.91 \pm 0.16$ \\
pH & $8.50 \pm 0.06$ & & $8.65 \pm 0.05$ \\
Turbidity & $10.40 \pm 1.37$ & & $1.58 \pm 0.33$ \\
\hline
\end{tabular}

versible organ damage. On the other hand, gills obtained from fish collected at Paraty Bay presented HAI between 11 and 20, indicating slight organ damage.

The two bays showed a high incidence of histological changes in the gills of the two fish species. The observed histological changes included epithelial lifting, interstitial edema, epithelial hyperplasia, leukocyte infiltration, lamellar epithelium hyperplasia, lamellar fusion, vasodilatation, lamellar blood congestion, aneurysm, and necrosis (Fig. 2).

Based on the frequency of histological changes (Table 2), stage III changes were less common in fish species collected in Paraty Bay, whereas stage I and II changes were often found in both sites.

\section{Mucous cell}

Mucous cells in the two examined species work as pavements for both filaments and lamellae, they had a positive response to $\mathrm{PAS}$ and $\mathrm{AB}$ staining, and this outcome indicated the presence of neutral and acid glycoconjugates, respectively (Fig. 3).

Positive cell counting to assess neutral mucus showed statistical difference in mucous cells of gills collected from fish belonging to the species Menticirrhus americanus. However, Micropogonias furnieri collected in Paraty Bay had smaller amounts of neutral mucous cells (Fig. 4a). The counting of cells positive for mucous acid secretion indicated a statistically significant difference between sites in both species (Paraty and Sepetiba bays). This result shows that fish collected at Paraty Bay have a smaller number of cells than those collected from Sepetiba Bay (Fig. 4b).

\section{DISCUSSION}

Sea and estuarine surfaces allow water to gain oxygen through the atmospheric gas exchange. Fish can absorb oxygen from water and transfer it to their bloodstream through the gills (Francis-Floyd, 2003). The amount of oxygen dissolved in one liter of water is referred to as dissolved oxygen (DO). Some researchers use DO monitoring as a water-quality indicator in coastal and estuarine areas (Jack et al., 2009) because reduced oxygen levels in water increase blood flow in fish gills; assumingly, this process is the cause for changes in the gills (Booth, 1979). The mean DO concentrations in Sepetiba and Paraty bays were within limits recommended by CONAMA.

The $\mathrm{pH}$ is the indicator to measure the acidity or alkalinity of water; therefore, it is essential to measure this parameter to control pollution levels, since water $\mathrm{pH}$ has a significant effect on the metabolism of aquatic organisms (Boyd, 1995). We found no show significant differences between $\mathrm{pH}$ values.

Turbidity is an important test to measure the quality of water. Suspended and dissolved materials such as clay scatter and absorb light, rather than transmit it in straight lines (Rice et al., 1980). The high turbidity rate found in Sepetiba Bay indicates high concentrations of suspended sediments in the site. These sediments may cause gill clogging and, resulting in lack of oxygen, a factor that can compromise gill tissues.

Research indicates that metals resulting from industrial centers are the main contaminants of Sepetiba Bay (Morales et al., 2019). Previous studies (Wasserman et al., 2001; Molisani et al., 2004; Pizzochero et al., 2019) of sediment and water quality in Sepetiba Bay showed a significantly higher heavy metal contamination. In this study, the parameters analyzed were within limits established by CONAMA in the Paraty and Sepetiba bays. Thus the histological changes could be caused by the presence of heavy metals in the water. This result confirms the hypothesis that Sepetiba Bay is at a high risk of chemical contamination by heavy metals and detergents. The gills of fish (M. americanus and M. furnieri) collected at the reference site in Paraty Bay showed lower histopathological changes than those from Sepetiba Bay. Kim et al. (2001) demonstrated that histopathological changes in fish tissues are relevant biomarkers to measure the impact of toxic substances since they reflect changes in biochemical functions.

Interstitial edema and leukocyte infiltrations are more often found in case of ecological disturbances such as red tides, as well as in animals exposed to chemical pollutants like heavy metals and certain pesticides, and to doses of therapeutic formalin or hydrogen peroxide (Skidmore \& Tovell, 1972; Yang \& Albright, 1992). These changes reflect disturbances in osmotic pressure regulation (Strzyżewska et al., 2016). In total, $100 \%$ of fish collected at Sepetiba Bay presented both of the assessed changes. M. americanus specimens collected at Paraty Bay recorded $58.3 \%$ of interstitial edema and $83.3 \%$ of leukocyte infiltration, whereas M. furnieri recorded $77.8 \%$ of interstitial edema and $88.9 \%$ of leukocyte infiltration. 
Table 2. The occurrence of histological changes in gills of Menticirrhus americanus and Micropogonias furnieri collected from Paraty and Sepetiba bays. Number of examined individuals in brackets.

\begin{tabular}{llllll}
\hline \multirow{2}{*}{ Histological changes } & \multicolumn{2}{c}{ Paraty Bay } & & \multicolumn{2}{c}{ Sepetiba Bay } \\
\cline { 2 - 3 } \cline { 5 - 6 } & M. americanus & M. furnieri & & M. americanus & M. furnieri \\
\hline Epithelial lifting & $41.7 \%(5)$ & $38.9 \%(7)$ & & $91.7 \%(11)$ & $100.0 \%(16)$ \\
Interstitial edema & $58.3 \%(7)$ & $77.8 \%(14)$ & & $100.0 \%(12)$ & $100.0 \%(16)$ \\
Leukocyte infiltration & $83.3 \%(10)$ & $88.9 \%(16)$ & & $100.0 \%(12)$ & $100.0 \%(16)$ \\
Lamellar hyperplasia & $58.3 \%(7)$ & $66.7 \%(12)$ & & $91.7 \%(11)$ & $100.0 \%(16)$ \\
Lamellar fusion & $41.7 \%(5)$ & $38.9 \%(7)$ & & $100.0 \%(12)$ & $87.5 \%(14)$ \\
Vasodilation & $91.7 \%(11)$ & $94.4 \%(17)$ & & $100.0 \%(12)$ & $100.0 \%(16)$ \\
Lamellar blood congestion & $83.3 \%(10)$ & $94.4 \%(17)$ & & $100.0 \%(12)$ & $100.0 \%(16)$ \\
Aneurism & $25.0 \%(3)$ & $33.3 \%(6)$ & & $100.0 \%(12)$ & $100.0 \%(16)$ \\
Necrosis & $16.7 \%(2)$ & $11.1 \%(2)$ & & $100.0 \%(12)$ & $93.8 \%(15)$ \\
Total & 12 & 18 & & 12 & \\
\hline
\end{tabular}

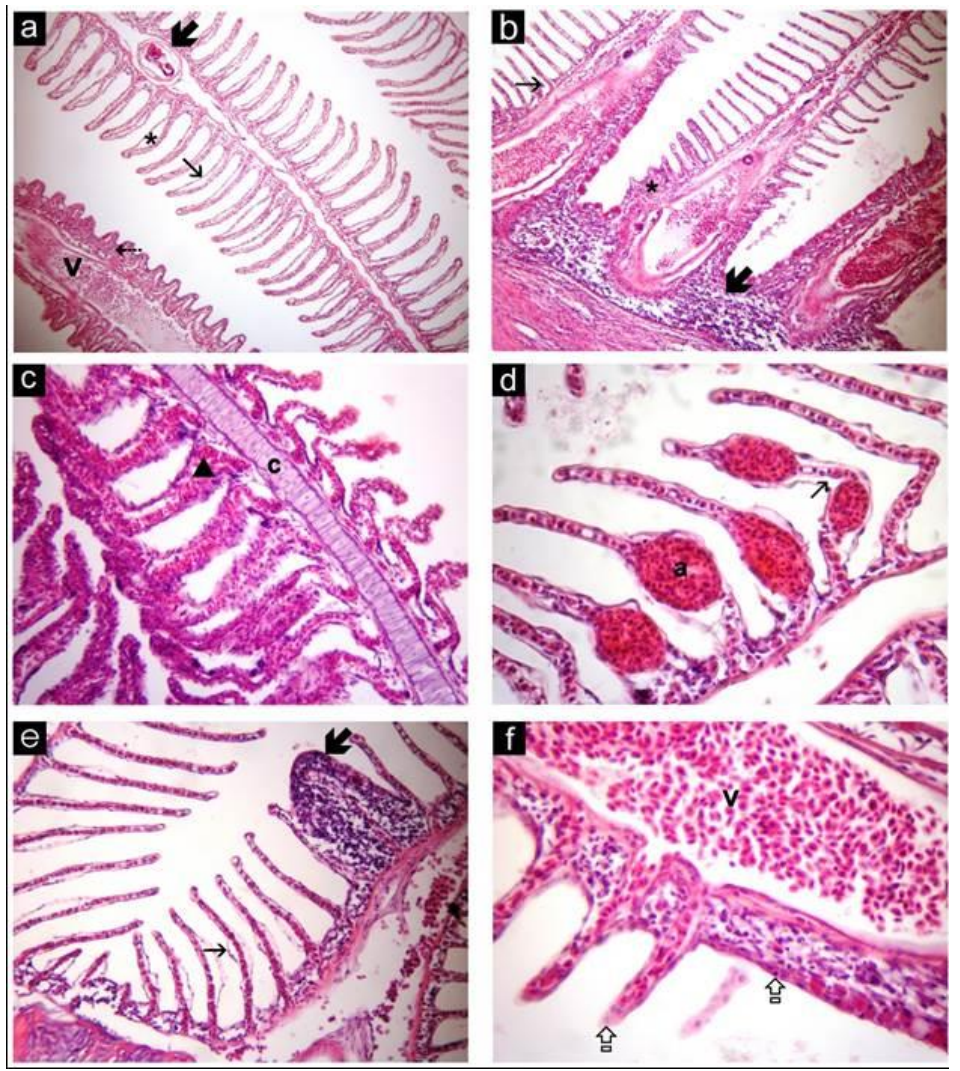

Figure 2. Description of histological changes in gills of fish collected at Sepetiba Bay. a) Presence of epithelial detachment areas - epithelial lifting $(*)$; vacuolation of interstitial space edema $(\rightarrow)$; oval structure of eosinophilic coloration with delimited borders - parasite $(\boldsymbol{K})$; epithelial lining proliferation - hyperplasia of the lamellar epithelium $(\rightarrow)$ and vasodilation (v) 300x, Micropogonias furnieri, b) presence of inflammatory cells - leukocyte infiltration ( $\boldsymbol{K})$; epithelial lifting $(\rightarrow$ ); and loss of lamellar architecture organization - lamellar fusion (*) 300x, Menticirrhus americanus, c) agglomerated red blood cells - lamellar blood congestion (*) and elastic cartilage (c) 630x, M. furnieri, d) lamellar dilation is observed due to agglomeration of red blood cells - aneurism (a) and epithelial lifting $(\rightarrow)$ 1150x. M. americanus, e) epithelial lifting $(\rightarrow)$ and leukocyte infiltration $(\boldsymbol{K})$ 630x, f) presence of eosinophilic cytoplasm and necrotic nuclei - necrosis (合) and vasodilatation (v) 1310x, M. furnieri.

Lamellar epithelium hyperplasia is often associated with exposure to waterborne irritants such as ammonia and microorganisms (Karges \& Woodward, 1984) and high copper sulfate concentrations (Wani et al., 2011). This process results from their chronic exposure to waterborne irritants such as ammonia. This change 

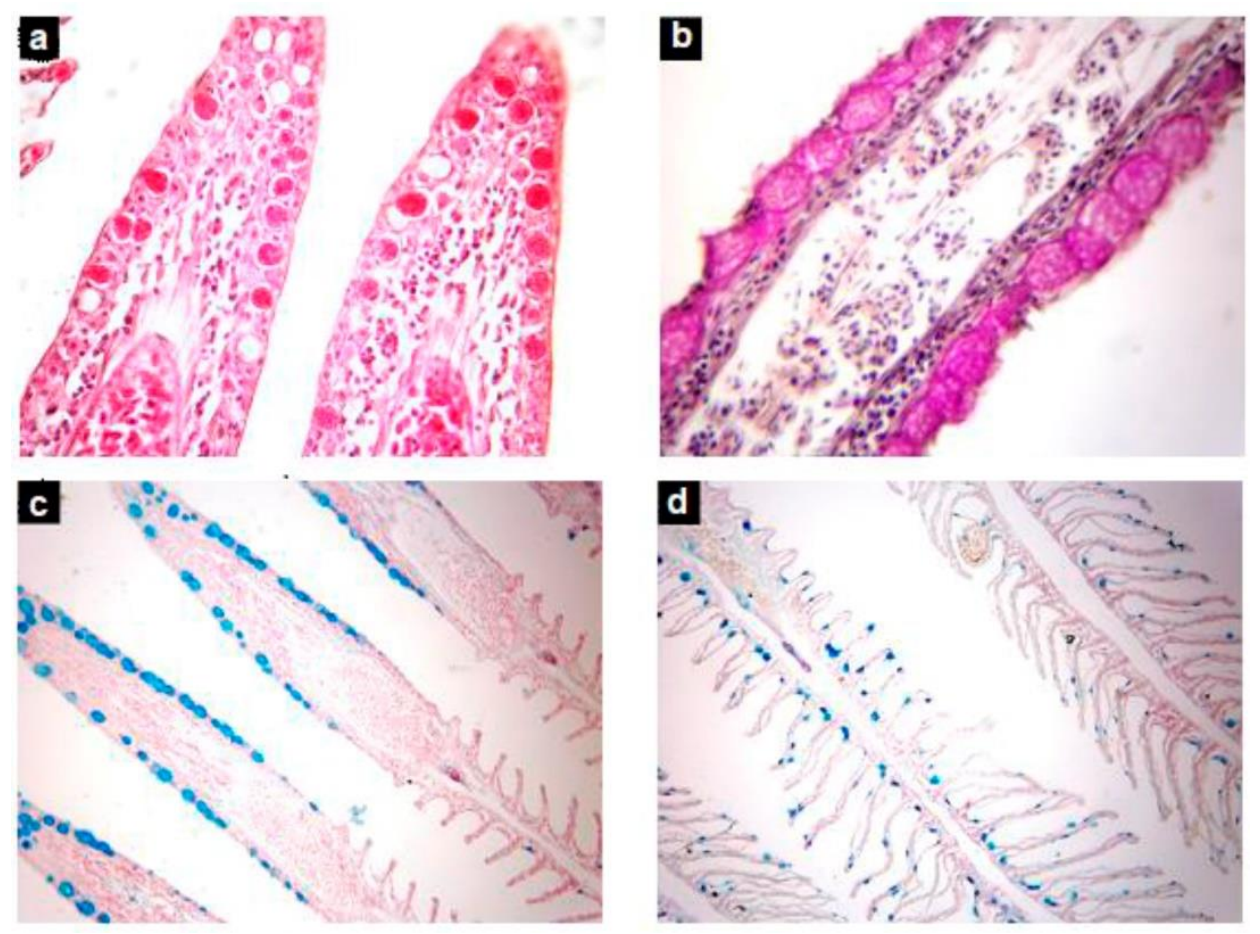

Figure 3. Histology and histochemistry in gills: hematoxylin and eosin (HE), periodic acid-Shiff (Santos et al., 2011) and Alcian Blue (AB) pH 2.5 in gills. a) HE-staining displays mucous cell population, Micropogonias furnieri from Paraty Bay, b) all cells positive for neutral mucus (Santos et al.) are magenta at the secondary lamellae, M. furnieri from Sepetiba Bay, c) acid mucous secretion (AB) stained at the secondary lamellae, Menticirrhus americanus from Sepetiba Bay, d) uniform distribution of acid mucous (AB) in lamellae, M. americanus from Sepetiba Bay.
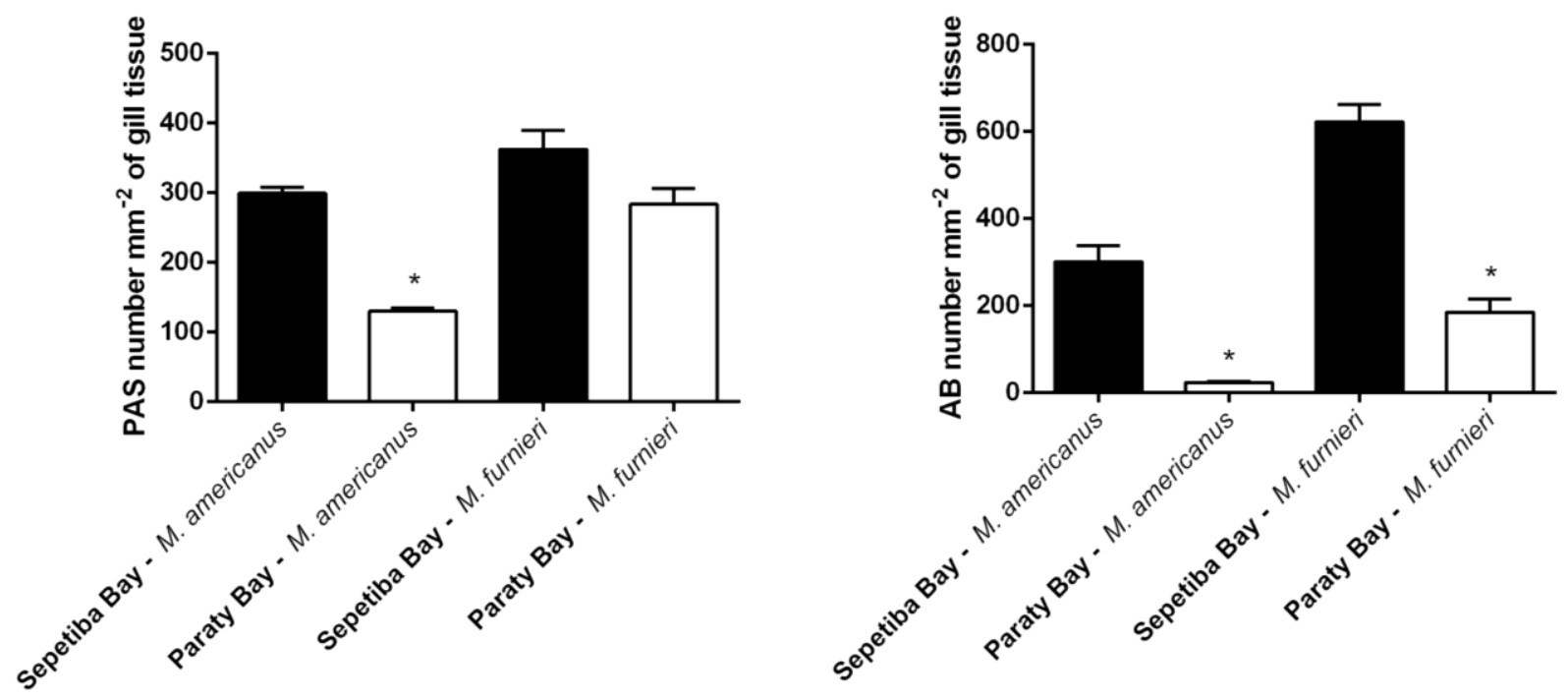

Figure 4. Effects of acid and neutral mucous secretion increase. Data ( $\mathrm{n}=10$ per group) are expressed as mean \pm standard deviation. $* P<0.05$ group Paraty Bay $\times$ Sepetiba Bay.

happens when cells derived from the primary lamellae migrate distally; such migration causes cell accumulation in the secondary lamellae anterior border (Rogers, 2007). Cell accumulation can increase the number of mucous cells at the lamellae; while significantly reducing the respiratory area. Gusmão et al. (2012) and Movahedinia et al. (2012) also observed the histopathological effects of crude oils and their byproducts. Lamellar epithelium hyperplasia was less often found in animals collected in Paraty Bay. 
Secondary lamellar fusion is likely caused by severe lamellar hyperplasia leading to the partial or total fusion of lamellar capillaries within a hyperplastic epithelial mass. However, the proliferation of epithelial cells is often lower than that of hyperplastic changes caused by modifications in mucus consistency. These changes have been associated with chronic effects caused by aluminum, as described in brown trout Salmo trutta (Karlsson-Norrgren et al., 1986). Secondary lamellar fusion, severe lamellar hyperplasia, and lamellar epithelium hyperplasia represent the fastest and easiest adaptation to low water quality, decreased respiratory surface, and increased diffusion distance (Sollid \& Nilsson, 2006). Lamellar fusion was the less abundant stage I change found in fish collected at Paraty Bay.

Epithelial lifting is one of the earliest histological changes observed in gills exposed to toxic substances such as oils, detergents, ammonia, phenols, acids, and metals such as mercury (Poleksic \& MitrovicTutundzic, 1994). The separation and lifting of lamella epithelial layers increase the intracellular spaces between the pillar system and the epithelial lining of secondary lamellae (Elshaer et al., 2015). These adaptive responses avoid the entry of xenobiotics in the organism (Simonato et al., 2008). Based on the results, epithelial lifting was observed in $41.7 \%$ of $M$. americanus. In $38.9 \%$ of $M$. furnieri collected at Paraty Bay, as well as in $91.7 \%$ of M. americanus and $100.0 \%$ of M. furnieri from Sepetiba Bay.

In total, $100 \%$ of fish collected at Sepetiba Bay presented vasodilation, whereas $91.7 \%$ of $M$. americanus and $94.4 \%$ of $\mathrm{M}$. furnieri collected at Paraty Bay recorded vasodilation. This outcome suggests the severe exposure of these specimens to water pollutants (Gomes et al., 2012). Fish subjected to stressful conditions can present vascular changes in lamellae; their response to such exposure can be dysfunctional and impair their physiology (Heath, 1995; Lima et al., 2006).

Lamellar blood congestion was found in all (100\%) specimens collected at Sepetiba Bay, and in most specimens collected at Paraty Bay. There were microscopic damages and losses of double-concave cells (pillar cells) in these fish; consequently, capillaries of the respiratory lamella fused and formed a uniform space filled with blood. This process led to lamella dilatation and lamellar blood congestion in other fish species (Strzyżewska et al., 2016). Lamellar blood congestion can impair gills' gas-exchange function and break pillar cells; thus, it can hinder their supporting capacity and, consequently, cause structural lamellar disorder (Gomes et al., 2012).
An aneurysm is characterized by blood leakage within the lamellae and by the pillar cell system's rupture, with subsequent dilation of blood vessels (Martinez et al., 2004). It appeared to reflect a deleterious effect of xenobiotics on branchial tissue (Simonato et al., 2008); moreover, it is a severe and often irreversible change. Aneurysm was found in $100 \%$ of fish collected at Sepetiba Bay, whereas fish collected at Paraty Bay recorded a low aneurysm rate. The incidence of aneurysms in the selected fish species may be associated with their eating habits since the organic matter found in the sediment had accumulated pollutants (Stehr et al., 1998). Lamellar aneurysms were also observed in the gills of fish exposed to cadmium, a heavy metal often used in experimental toxicological studies. This change results in significant cadmium accumulation in the environment and industrial and domestic waste (Garcia-Santos et al., 2007).

Necrosis is characterized by eosinophilic cytoplasm and necrotic nuclei (pyknosis, karyorrhexis, and karyolysis). This phenomenon is typical of the degenerative process. Necrosis of epithelial cells in the gills is often observed after fish's exposure to toxins (Rogers, 2007). They can be the result of prolonged exposure to irritants, including water suspensions, which can cause turbidity (Strzyżewska et al., 2016). This irreversible histological change was found in almost all fish collected at Sepetiba Bay, whereas the ones collected at Paraty Bay presented a low occurrence of it.

\section{Mucous cells analysis}

Several studies have highlighted the vital role played by mucous cells in fish gills (Saboaia-Moraes et al., 2005). In physiological terms, mucus secretion is primarily associated with respiratory tract lubrication and protection against pathogenic microorganisms (Zaccone et al., 1989; Whitear \& Mittal, 2006). This secretion also plays a vital role in ion regulation and diffusion in fish (Handy et al., 1989). Glycoconjugates secreted on the surface of mucous cells play an important role in lubrication, as well as in the protection against, and inhibition of, microorganisms (Díaz et al., 2001). Fish collected from Paraty Bay had a smaller number of mucous cells than the ones collected from Sepetiba Bay. The increased number of mucous cells in fish from Sepetiba Bay may be due to a disturbance in the aquatic ecosystem (Ledy et al., 2003). The hypersecretion of gill mucus may be a non-specific response from fish subjected to acidic conditions (Karlsson-Norrgren et al., 1986) and from fish exposed to pollutants of distinct nature (Mallatt, 1985). 


\section{CONCLUSION}

In conclusion, we observed histological changes and a higher presence of mucus in fish gills. This result suggests contamination of the assessed sites by nonspecific xenobiotics. Histological changes seen in the gill epithelium of Menticirrhus americanus and Micropogonias furnieri could differentiate Paraty Bay (reference area) from Sepetiba Bay (potentially contaminated).

The higher incidence of branchial lesions shows that the fish in Sepetiba Bay are experiencing stress due to water pollutants (heavy metals and solvents). Although further studies are still needed to confirm our result, we can suggest that histological changes can be considered useful biomarkers to assess environmental contamination in Paraty and Sepetiba bays.

\section{ACKNOWLEDGMENT}

This research was funded by Coordenação de Aperfeiçoamento de Pessoal de Nível Superior - Brasil (CAPES) - Finance Code 001.

\section{REFERENCES}

Akinloye, O., Fawole, O., Adewoye, S. \& Tolulope, A. 2009. Pathologic lesions in the gills of Clarias gariepinus exposed to sublethal concentrations of soap and detergent effluents. Journal of Cell and Animal Biology, 3(5): 78-82.

Ambedkar, G. \& Muniyan, M. 2011. Accumulation of metals in the five commercially important freshwater fishes available in vellar river, Tamil Nadu, India. Archives of Applied Science Research, 3(3): 261-264.

Au, D.W. 2004. The application of histo-cytopathological biomarkers in marine pollution monitoring: a review. Marine Pollution Bulletin, 48: 817-834. doi: 10.1016/j.marpolbul.2004.02.032

Barbiéri, E.B. \& Kronemberger, D.M.P. 1994. Climatology in the south-southwest of the State of Rio de Janeiro. Caderno de Geociências, 12: 57-73.

Benli, A.C., Koksal, G. \& Ozkul, A. 2008. Sublethal ammonia exposure of Nile tilapia (Oreochromis niloticus L.): effects on gill, liver and kidney histology. Chemosphere, 72: 1355-1358. doi: 10.1016/j.chemosphere.2008.04.037

Bernet, D., Schmidt, H., Meier, W., Burkhardt-Holm, P. \& Wahli, T. 1999. Histopathology in fish: proposal for a protocol to assess aquatic pollution. Journal of Fish Diseases, 22: 25-34. doi: 10.1046/j.1365-2761.1999. 00134.x
Bertoletti, E. 2008. Ecotoxicologia aquática: princípios e aplicações. Rima, San Pablo.

Booth, J.H. 1979. The effects of oxygen supply, epinephrine, and acetylcholine on the distribution of blood flow in trout gills. Journal of Experimental Biology, 83: 31-39.

Boyd, C.E. 1995. Bottom soils, sediment, and pond aquaculture. Chapman and Hall, New York.

Camargo, M.M.P. \& Martinez, C.B.R. 2007. Histopathology of gills, kidney and liver of a Neotropical fish caged in an urban stream. Neotropical Ichthyology, 5: 327-336.

Cardoso, A.G.A., Boaventura, G.R., Silva Filho, E.V. \& Brod, J.A. 2001. Metal distribution in sediments from the Ribeira Bay, Rio de Janeiro-Brazil. Journal of the Brazilian Chemical Society, 12: 767-774.

Creed, J.C., Pires, D.O. \& Figueiredo, M.A. 2007. Biodiversidade marinha da Baía da Ilha Grande. Ministério do Meio Ambiente, Secretaria Nacional de Biodiversidade e Florestas, Departamento de Conservação da Biodiversidade, Brasilia.

Dezfuli, B., Giari, L., Konecny, R., Jaeger, P. \& Manera, M. 2003. Immunohistochemistry, ultrastructure and pathology of gills of Abramis brama from Lake Mondsee, Austria, infected with Ergasilus sieboldi (Copepoda). Diseases of Aquatic Organisms, 53(3): 257-262.

Díaz, A., García, A., Devincenti, C. \& Goldemberg, A.L. 2001. Mucous cells in Micropogonias furnieri gills: histochemistry and ultrastructure. Anatomia, Histologia, Embryologia, 30(3): 135-139.

Elnaggar, A., Mahmoud, S. \& Tayel, S. 2009. Bioaccumulation of some heavy metals and histopathological alterations in liver of Oreochromis niloticus in relation to water quality at different localities along the river Nile, Egypt. World Journal of Fish and Marine Sciences, 1(2): 105-114.

Elshaer, F., Allah, H. \& Bakry, S. 2015. Histopathological alterations in gills of some poecilid fishes after exposure to bisphenol- $a$. World Journal of Fish and Marine Sciences, 5(6): 693-700.

Evans, D.H. 1997. Acid-base regulation. In: Evans, D.H. \& Claiborne, J.B. (Eds.). The physiology of fishes. Taylor \& Francis, Abingdon, pp. 177-198.

Evans, D.H., Piermarini, P.M. \& Choe, K.P. 2005. The multifunctional fish gill: dominant site of gas exchange, osmoregulation, acid-base regulation, and excretion of nitrogenous waste. Physiological Reviews, 85: 97-177. doi: 10.1152/physrev.00050. 2003

Fernandes, M.N. \& Mazon, A.F. 2003. Environmental pollution and fish gill morphology. In: Val, A.L. \& 
Kapoor, B.G. (Eds.). Fish adaptations. Science Publishers, Boca Raton, pp. 203-231.

Fernandes, M.N., Moron, S.E. \& Sakuragui, M.M. 2007. Gill morphological adjustments to environment and the gas exchange function. In: Fernandes, M.N., Rantin, F.T., Glass, M.L. \& Kapoor, B.G. (Eds.). Fish respiration and environment. Science Publishers, Boca Raton, pp. 93-120.

Figueiredo, L.H.M., Wagener, A.d.L.R., Dagaut, J. \& Saliot, A. 2008. Non-aromatic hydrocarbons in recent sediments of Sepetiba and Ilha Grande Bays, Brazil. Journal of the Brazilian Chemical Society, 19: 516527.

Flores-Lopes, F. \& Thomaz, A. 2011. Histopathologic alterations observed in fish gills as a tool in environmental monitoring. Brazilian Journal of Biology, 71: 179-188.

Franchini, A., Alessandrini, F. \& Bolognani-Fantin, A. 1994. Gill morphology and ATPase activity in the goldfish Carassius carassius var. auratus exposed to experimental lead intoxication. Bollettino di Zoologia, 61(1): 29-37.

Francis-Floyd, R. 2003. Dissolved oxygen for fish production. Florida Cooperative Extension Service, Department of Fisheries and Aquatic Sciences, University of Florida, Florida.

Freret-Meurer, N.V., Andreata, J.V., Meurer, B.C., Manzano, F.V., Baptista, M.G.S., Teixeira, D.E. \& Longo, M.M. 2010. Spatial distribution of metals in sediments of the Ribeira Bay, Angra dos Reis, Rio de Janeiro, Brazil. Marine Pollution Bulletin, 60: 627629. doi: 10.1016/j.marpolbul.2010.01.023

Garcia-Santos, S., Monteiro, S., Rocha, M. \& FontaínhasFernandes, A. 2007. Histological alterations in gills of Nile tilapia Oreochromis niloticus caused by cadmium. Arquivo Brasileiro de Medicina Veterinária e Zootecnia, 59(2): 376-381.

Gomes, I.D., Nascimento, A.A., Sales, A. \& Araújo, F.G. 2012. Can fish gill anomalies be used to assess water quality in freshwater Neotropical systems? Environmental Monitoring and Assessment, 184: 5523-5531. doi: 10.1007/s10661-011-2358-2

Gusmão, E.P., Rodrigues, R.V., Moreira, C.B., Romano, L.A., Sampaio, L.A. \& Miranda-Filho, K.C. 2012. Growth and histopathological effects of chronic exposition of marine pejerrey Odontesthes argentinensis larvae to petroleum water-soluble fraction (WSF). AMBIO: a Journal of the Human Environment, 41: 456-466. doi: 10.1007/s13280-0120259-4

Handy, R., Eddy, F. \& Romain, G. 1989. In vitro evidence for the ionoregulatory role of rainbow trout mucus in acid, acid/aluminum and zinc toxicity. Fish Biology, 35(5): 737-747.
Heath, A.G. 1995. Water pollution and fish physiology. CRC Press, Boca Raton.

Heier, L.S., Lien, I.B., Stromseng, A.E., Ljones, M., Rosseland, B.O., Tollefsen, K.E. \& Salbu, B. 2009. Speciation of lead, copper, zinc and antimony in water draining a shooting range-time dependant metal accumulation and biomarker responses in brown trout (Salmo trutta L.). Science of the Total Environment, 407: 4047-4055. doi: 10.1016/j.scitotenv.2009.03.002

Hemmadi, V. 2017. A critical review on integrating multiple fish biomarkers as indicator of heavy metals contamination in aquatic ecosystem. International Journal of Bioassays, 6(9): 5494-5506.

Hinton, D.E., Baumann, P.C., Gardner, G.R., Hawkins, W.E., Hendricks, J.D., Murchelano, R.A. \& Okihiro, M.S. 1992. Histopathologic biomarkers. Biomarkers: biochemical, physiological, and histological markers of anthropogenic stress. Lewis Publishers, Boca Raton, pp. 55-195.

Instituto Brasileiro de Geografia e Estatística (IBGE). 2016. Base cartográfica contínua, ao milionésimo. Instituto Brasileiro de Geografia e Estatística, Rio de Janeiro.

Jack, J.P., Abdsalam, A.T. \& Khalifa, N.S. 2009. Assessment of dissolved oxygen in coastal waters of Benghazi, Libya. Journal of the Black Sea/Mediterranean Environment, 15: 135-156.

Johnson, L.L., Stehr, C.M., Olson, O.P., Myers, M.S., Pierce, S.M., Wigren, C.A., McCain, B.B. \& Varanasi, U. 1993. Chemical contaminants and hepatic lesions in winter flounder (Pleuronectes americanus) from the northeast coast of the United States. Environmental Science \& Technology, 27: 2759-2771. doi: 10.1021/ es00049a015

Karges, R.G. \& Woodward, B. 1984. Development of lamellar epithelial hyperplasia in gills of pantothenic acid-deficient rainbow trout, Salmo gairdneri Richardson. Journal of Fish Biology, 25: 57-62. doi: 10.1111/j.1095-8649.1984.tb04850.x

Karlsson-Norrgren, L., Bjorklund, I., Ljungberg, O. \& Runn, P. 1986. Acid water and aluminum exposure; experimentally induced gill lesions in brown trout (Salmo trutta). Journal of Fish Diseases, 9: 11-25.

Kim, J.-H., Wang, S.-Y., Kim, I.-C., Ki, J.-S., Raisuddin, S., Lee, J.-S. \& Han, K.-N. 2008. Cloning of a river pufferfish (Takifugu obscurus) metallothionein cDNA and study of its induction profile in cadmium-exposed fish. Chemosphere, 71: 1251-1259. doi: 10.1016/j. chemosphere.2007.11.067

Lacerda, L., Wc, P. \& Fiszman, M. 1982. Níveis de metais pesados em sedimentos marinhos da Baía da Ribeira, Angra dos Reis. Ciencia e Cultura, 34: 921-924.

Ledy, K., Giambérini, L. \& Pihan, J. 2003. Mucous cell responses in gill and skin of brown trout Salmo trutta 
fario in acidic, aluminum-containing stream water. Diseases of Aquatic Organisms, 56(3): 235-240.

Lima, L.C., Ribeiro, R.C.L. \& Melo, D.C. 2006. Stress in fishes. Revista Brasileira de Reprodução Animal, 30: 113-117.

Livingstone, D.R. 2003. Oxidative stress in aquatic organisms in relation to pollution and aquaculture. Veterinaire, 154(6): 427-430.

Mallatt, J. 1985. Fish gill structural changes induced by toxicants and other irritants: a statistical review. Canadian Journal of Fisheries and Aquatic Sciences, 42(4): 630-648.

Martinez, C.B.R., Nagae, M.Y., Zaia, C.T.B.V. \& Zaia, D.A.M. 2004. Acute morphological and physiological effects of lead in the neotropical fish Prochilodus lineatus. Brazilian Journal of Biology, 64: 797-807.

Mazon, A.F., Cerqueira, C.C.C., Monteiro, E.A.S. \& Fernandes, M.N. 1999. Acute copper exposure in freshwater fish: morphological and physiological effect. In: Val, A.L. (Ed.). Biology of tropical fishes. Instituto Nacional de Pesquisas da Amazônia, Manaus, pp. 263-275.

Menezes, N.A. \& Figueireido, J.L. 1980. Manual de peixes marinhos do sudeste do Brasil. Museu de Zoologia, Universidade de São Paulo, São Paulo.

Molisani, M.M., Marins, R.V., Machado, W., Paraquetti, H.H.M., Bidone, E.D. \& Lacerda, L.D. 2004. Environmental changes in Sepetiba Bay, SE Brazil. Regional Environmental Change, 4: 17-27. doi: 10.1007/s10113-003-0060-9.

Monperrus, M., Point, D., Grall, J., Chauvaud, L., Amouroux, D., Bareille, G. \& Donard, O. 2005. Determination of metal and organometal trophic bioaccumulation in the benthic macrofauna of the Adour estuary coastal zone (SW France, Bay of Biscay). Journal of Environmental Monitoring, 7: 693700. doi: $10.1039 / \mathrm{b} 500288 \mathrm{e}$

Morales, S., Guerra, J., Nunes, M., Souza, A. \& Geraldes, M. 2019. Evaluation of the environmental state of the western sector of Sepetiba Bay (SE Brazil): trace metal contamination. Journal of Sedimentary Environments, 4: 174-188. doi: 10.12957/jse.2019.43764

Movahedinia, A., Behrooz, A. \& Mahmood, B. 2012. Gill histopathological lesions of the sturgeons. Asian Journal of Animal and Veterinary Advances, 7: 710717.

Nascimento, A.A., Araujo, F.G., Gomes, I.D., Mendes, R.M. \& Sales, A. 2012. Fish gills alterations as potential biomarkers of environmental quality in a eutrophized tropical river in south-eastern Brazil. Anatomia, Histologia, Embryologia, 41: 209-216. doi: 10.1111/j.1439-0264.2011.01125.x

Pizzochero, A.C., De la Torre, A., Sanz, P., Navarro, I., Michel, L.N., Lepoint, G., Das, K., Schnitzler, J.G.,
Chenery, S.R., McCarthy, I.D., Malm, O., Dorneles, P.R. \& Martínez, M.Á. 2019. Occurrence of legacy and emerging organic pollutants in whitemouth croakers from southeastern Brazil. Science of the Total Environment, 682: 719-728. doi: 10.1016/ j.scitotenv. 2019.05.213

Poleksic, V. \& Mitrovic-Tutundzic, V. 1994. Fish gills as a monitor of sublethal and chronic effects of pollution. In: R. Muller \& R. Lloyd (Eds.). Sublethal and chronic effects of pollutants on freshwater fish. Cambridge University, Cambridge, pp. 339-352.

Rajamanickam, V. \& Narayanan, M. 2009. Heavy metal induced histopathological alterations in selected organs of the Cyprinus carpio L. (common carp). International Journal of Environmental Research, 3(1): 95-100.

Rice, E.W., Baird, R.B. \& Eaton, A.D. (Eds.). 1980. Standard methods for the examination of water and wastewater. American Public Health Association, Washington, DC.

Roberts, S. \& Powell, M. 2003. Comparative ionic flux and gill mucous cell histochemistry: effects of salinity and disease status in Atlantic salmon (Salmo salar L.). Comparative Biochemistry and Physiology Part A: Molecular \& Integrative Physiology, 134(3): 525-537.

Rogers, D.F. 2007. Physiology of airway mucus secretion and pathophysiology of hypersecretion. Respiratory Care, 52: 1134-1149.

Saboaia-Moraes, S., Hernandez-Blazquez, F.J., Mota, D. \& Bittencourt, A. 2005. Mucous cell type in the branchial epithelium of the euryhaline fish Poecilia vivipara. Fish Biology, 49(3): 545-548.

Samanidou, V., Papadoyannis, I. \& Vasilikiotis, G. 1991. Vertical distribution of heavy metals in sediments from rivers in northern Greece. Journal of Environmental Science and Health Part A: Environmental Science and Engineering and Toxicology, 26: 13451361. doi: 10.1080/10934529109375702

Santos, T., Gomes, V., José, M., Passos, A., Rocha, A., Rocha, J., Salaroli, R. \& Van Ngan, P. 2011. Histopathological alterations in gills of juvenile Florida pompano Trachinotus carolinus (Perciformes, Carangidae) following sublethal acute and chronic exposure to naphthalene. Pan-American Journal of Aquatic Sciences, 6: 109-120.

Schwaiger, J., Wanke, R., Adam, S., Pawert, M., Honnen, W. \& Triebskorn, R. 1997. The use of histopathological indicators to evaluate contaminant-related stress in fish. Journal of Aquatic Ecosystem Stress and Recovery, 6: 75-86. doi: 10.1023/a:1008212000208

Simonato, J.D., Guedes, C.L.B. \& Martinez, C.B.R. 2008. Biochemical, physiological, and histological changes in the neotropical fish Prochilodus lineatus exposed to 
diesel oil. Ecotoxicology and Environmental Safety, 69: 112-120. doi: 10.1016/j.ecoenv. 2007.01.012

Skidmore, J.F. \& Tovell, P.W.A. 1972. Toxic effects of zinc sulphate on the gills of rainbow trout. Water Research, 6(3): 217-228.

Sollid, J. \& Nilsson, G.E. 2006. Plasticity of respiratory structures-adaptive remodeling of fish gills induced by ambient oxygen and temperature. Respiratory Physiology \& Neurobiology, 154: 241-251. doi: 10.1016/ j.resp.2006.02.006

Sorour, J. 2001. Ultrastructural variations in Lethocerus niloticum (Insecta: Hemiptera) caused by pollution in Lake Mariut, Alexandria, Egypt. Ecotoxicology and Environmental Safety, 48: 268-274. doi: 10.1006/eesa. 2000.2003

Sousa, D., Almeida, Z. \& Carvalho-Neta, R. 2013. Integrated analysis of two biomarkers in Sciades herzbergii (Ariidae, Siluriformes), to assess the environmental impact at São Marcos' Bay, Maranhão, Brazil. Latin American Journal of Aquatic Research, 41(2): 305-312.

Stehr, C.M., Johnson, L.L. \& Myers, M.S. 1998. Hydropicvacuolation in liver of three species of fish from the U.S. West Coast: lesion description and risk assessment associated with contaminant exposure. Diseases of Aquatic Organisms, 32: 119-135.

Strzyżewska, E., Szarek, J. \& Babinska, I. 2016. Morphologic evaluation of the gills as a tool in the diagnostics of pathological conditions in fish and pollution in the aquatic environment: a review. Veterinarni Medicina, 61(3): 123-132.

Sweidan, A.H., El-Bendary, N., Hegazy, O.M., Hassanien, A.E. \& Snasel, V. 2015. Water pollution detection system based on fish gills as a biomarker. Procedia Computer Science, 65: 601-611. doi: 10.1016/j.procs.2015.09.004

Teh, S.J., Adams, S.M. \& Hinton, D.E. 1997. Histopathologic biomarkers in feral freshwater fish populations exposed to different types of contaminant stress. Aquatic Toxicology, 37: 51-70. doi: 10.1016/S0166-445X(96)00808-9

Thophon, S., Kruatrachue, M., Upatham, E.S., Pokethitiyook, P., Sahaphong, S. \& Jaritkhuan, S. 2003. Histopathological alterations of white seabass, Lates calcarifer, in acute and subchronic cadmium exposure. Environmental Pollution, 121: 307-320. doi: 10.1016/S0269-7491(02)00270-1

Van der Oost, R., Beyer, J. \& Vermeulen, N.P. 2003. Fish bioaccumulation and biomarkers in environmental risk assessment: a review. Environmental Toxicology and Pharmacology, 13: 57-149.
Vazzoler, A.E.A.M., Soares, L.S.H. \& Cunningham, P.T.M. 1999. Ictiofauna da costa brasileira. In: LoweMcConnel, R.H. (Ed.). Estudos de comunidades de peixes tropicais. Editora da Universidade de São Paulo, São Paulo, pp. 424-467.

Velmurugan, B., Selvanayagam, M., Cengiz, E.I. \& Unlu, E. 2009. Histopathological changes in the gill and liver tissues of freshwater fish, Cirrhinus mrigala exposed to dichlorvos. Brazilian Archives of Biology and Technology, 52: 1291-1296.

Verbost, P.M., Berntssen, M.H.G., Kroglund, F., Lydersen, E., Witters, H.E., Rosseland, B.O., Salbu, B. \& Bonga, S.E.W. 1995. The toxic mixing zone of neutral and acidic river water: acute aluminum toxicity in brown trout (Salmo trutta L.). Water, Air, and Soil Pollution, 85: 341-346. doi: 10.1007/ bf00476852

Wani, A., Sikdar-Bar, M., Borana, K., Khan, H.A., Andrabi, S.S.M. \& Pervaiz, P.A. 2011. Histopathological alterations induced in gill epithelium of African catfish, Clarias gariepinus, exposed to copper sulfate. Asian Journal of Experimental Biological Sciences, 2(2): 278-282.

Wanick, R., Kütter, V., Teixeira, C., Cordeiro, R. \& Santelli, R. 2011. Use of the digestive gland of the oyster Crassostrea rhizophorae (Guilding, 1828) as a bioindicator of $\mathrm{Zn}, \mathrm{Cd}$ and $\mathrm{Cu}$ contamination in estuarine sediments (south-east Brazil). Chemistry and Ecology, 28: 1-9. doi: 10.1080/02757540.2011.638 630

Wasserman, J.C., Figueiredo, A.M.G., Pellegatti, F. \& Silva-Filho, E.V. 2001. Elemental composition of sediment cores from a mangrove environment using neutron activation analysis. Journal of Geochemical Exploration, 72: 129-146. doi: 10.1016/S0375-6742 (01)00158-3

Whitear, M. \& Mittal, A. 2006. Surface secretions of the skin of Blennius (Lipophrys) pholis L. Fish Biology, 25(3): 317-331.

Yang, C.Z. \& Albright, L.J. 1992. Effects of the harmful diatom Chaetoceros concavicornis on respiration of rainbow trout Oncorhynchus mykiss. Diseases of Aquatic Organisms, 14: 105-114.

Zaccone, G., Salvatore, F., Ainis, L. \& Contini, A. 1989. Localization of calmodulin positive immunoreactivity in the surface epidermis of the brown trout, Salmo trutta. Histochemistry, 91(1): 13-16.

Zhou, Q., Zhang, J., Fu, J., Shi, J. \& Jiang, G. 2008. Biomonitoring: an appealing tool for assessment of metal pollution in the aquatic ecosystem. Analytica Chimica Acta, 606: 135-150. doi: 10.1016/j.aca.2007. 11.018 